\title{
Applying some biotic indices of macrobenthic invertebrates to assess water quality of Lake Manzala, Egypt.
}

\author{
Mohamed R. Fishar ${ }^{1}$; Khaled A. El-Damhogy ${ }^{2}$; Hesham R. A. Mola*1; \\ Mahmoud H. Hegab ${ }^{1}$ and Mustafa S. Abd El-Hameed ${ }^{1}$ \\ 1- National Institute of Oceanography and Fisheries, Cairo, Egypt. \\ 2- Zoology department, Faculty of Science, Al-Azhar University, Cairo, Egypt. \\ *Corresponding author E-mail: hesham_reda06@yahoo.com.
}

\section{ABSTRACT}

Water and macrobenthic invertebrate (MBI) samples were collected from nine stations of Lake Manzala during spring (May, 2014) and summer (August, 2014). Chemical parameters e.g. Dissolved Oxygen, Biological Oxygen Demand, Total Dissolved Solids, Ammonia, Nitrite, Orthophosphorus, Total Suspended Solids were measured for Nile Chemical Pollution Index (NCPI). Macrobenthic invertebrates were sorted, counted and identified for Biological Monitoring Working Party (BMWP) and Nile Biotic Pollution Index (NBPI) was conducted. The highest number of macrobenthic invertebrates and the best water quality was observed at the stations away from the source of pollution (Legan and Boom Station), while the lowest water quality and the lowest number of species were observed at Bahr El-Bakar and its discharged point.

The present study revealed that, the average score of NCBI was ranged between 33 during spring and 29 during summer, indicating heavily polluted ranges (26-35). In this work, 19 MBI species under 18 families were recorded; out of these 8 families are bioindicatory families (Viviparidae, Planorbidae, Lymnaeidae, Thiaridae, Physidae, Neritidae, Tubificidae and Chironomidae) which used in the applied biotic indices.

During spring, the average value of NCBI recorded high score, whereas BMWP-ASPT and NBPI-ASPT were decreased being 2.99 and 2.59 respectively. On the other hand during summer, the average value of NCBI recorded low score whereas BMWP-ASPT and NBPI-ASPT were increased. Regression values between the chemical index (NCBI) and BMWP-ASPT Index and NBPI Index showed a non significant values ( $\mathrm{p}$ value more than 0.05 ) during spring and summer. So, the present study concluded that, BMWP-ASPT and NBPI-ASPT Indices did not show a good indication to assess water quality of Lake Manzala and they were not matching with chemical index (NCBI) and more developments to these indices are needed to develop them according to the nature of the lake and their dominant macrobethic indicator species.

Keywords: Lake Manzala, water quality, biotic indices, regression analysis.

\section{INTRODUCTION}

Water quality monitoring is an important exercise, which helps in evaluating the nature and extent of pollution as well as effectiveness of pollution control measures. It also helps in determining the water quality trends and prioritizing pollution control effort (Sultana and Kala, 2012). Results of "bio-indication approaches" should also include a taxonomically-diverse group of indicator organisms, that shows a unique response to several different broad categories of stressors, as well as a select few organisms which are able to detect specific stresses of particular concern to individual 
monitoring programs (Karr, 1991\& 1996). The identification of these groups may provide an indicator of ecosystem health, and an early warning to implement intensive conservation efforts in advance of a collapse (Paine, 1966; Chapin, 1998\& 2000). Benthic invertebrates have been favored in environmental effects monitoring because they are sessile or limited in there range of movement and therefore can not avoid pollution (Gaufin, 1973).

They are commonly used as indicators in the evaluation of impacts to stream ecology and entire watersheds from a variety of point and non-point pollution sources (Plafkin et al. 1989; Lenat and Crawford 1994; Karr and Chu 1997; Barbour et al. 1999). Also, they are the most popular and commonly used group of freshwater organisms in assessing water quality (Sultana and Kala, 2012). Benthic communities are often used as biological indicators (e.g. the Water Framework Directive) because they can provide information on environmental conditions either due to the sensitivity of single species (indicator species) or because of some general features that makes them integrate environmental signals over a long period of time (Tagliapietra and Sigovini, 2010).

Many biotic indices are based on the pollution tolerance of macroinvertebrates, essentially, the development of the biotic index is an iterative process achieved by testing a putative index on different rivers or sites within a river system, or examining the response of the index to known pollution events (Fishar and Williams, 2008). Several authors have attempted to link biotic indices with habitat degradation (Balestrini et al., 2004) and lowland river eutrophication (Parr \& Mason, 2003), changing land use (Donohue et al., 2006), the impact of river impoundments (Ogbeibu \& Oribhador, 2002) and other human interventions such as sediment contamination (De Pauw \& Heylen, 2001). One of the simplest, and apparently more reliable methods for bioassessment of organic pollution using macro invertebrates was developed in the UK by the Biological Monitoring Working Party (BMWP). The first version of the BMWP score (ISO, 1979) scored each family present from 1 to 100 and had two scales one for depositing and the other for eroding habitats. The following year the scoring was simplified to 1-10 and the scale for depositing zones was excluded. Fishar and Williams (2008) develop an index of the UK by the Biological Monitoring Working Party (BMWP) to (BMWP-ASPT) which became applicable for use macro invertebrates to assess water quality in the River Nile.

Little information is known about the applications of biotic indices on Lake Manzala, so that, the present study describes the availability of two biotic indices, Biological Monitoring Working Party (BMWP-ASPT) and a Nile Biotic Pollution Index (NBPI-ASPT) using the macrobenthic invertebrates to assess water quality in Lake Manzala.

\section{MATERIALS AND METHODS}

\section{Study area}

Lake Manzala is the largest and the most productive of the northern Egyptian lakes (Khalil and Salib, 1986), it located in the north eastern part of the Nile Delta between Suez Canal and Damietta branch, and partly separated from the Mediterranean Sea by a narrow peninsula (Abdel-Mageed, 2007). It is $47 \mathrm{~km}$ long and $30 \mathrm{~km}$ wide (Zahran, 2008). Though Lake Manzala's unaltered depth is only four to five feet, alterations to the depth were made during the construction of the Suez Canal to allow the Canal to extend 29 miles lengthwise along the lake (Rogers et al., 2004).

The surface area of the lake has been decreasing steadily over the past few 
decades from $1709 \mathrm{~km} 2$ in 1907 to $1470 \mathrm{~km} 2$ in 1949 (Fouad, 1926) and to $1260 \mathrm{~km} 2$ during 1960's (Bishai and Youssef, 1977) reaching to $895 \mathrm{~km} 2$ in 1979 (AbdelGawad and El-Sayed, 1998). Now, the area of Lake Manzala has been reduced to only $120 \mathrm{~km} 2$ (Khalifa and Mageed, 2002). It is an eutrophic lake (Donia and Hussein, 2004). Although lake Manzala is a brackish lake because of its connection with Mediterranean sea, it sustains the maximum of marine and freshwater fish (khalil,1997).

Nine stations represented all lake habitats in the lake (Fig. 1 and Table 1) were selected for the present study; El-Serw Drain (Agriculture drain), El-Matariya (Fishermen activity and Agriculture drain), Legan (Away from pollution), Old Bahar El-Bakar Drain, Old Bahar El-Bakar Drain D.P. (discharge point), El-Genka (near from Hadous and Old Bahar El-Bakar Drains), New Bahar El-Bakar Drain, New Bahar El-Bakar Drain D.P. (discharge point) and El-Boom (near from New Bahar ElBakar Drain).

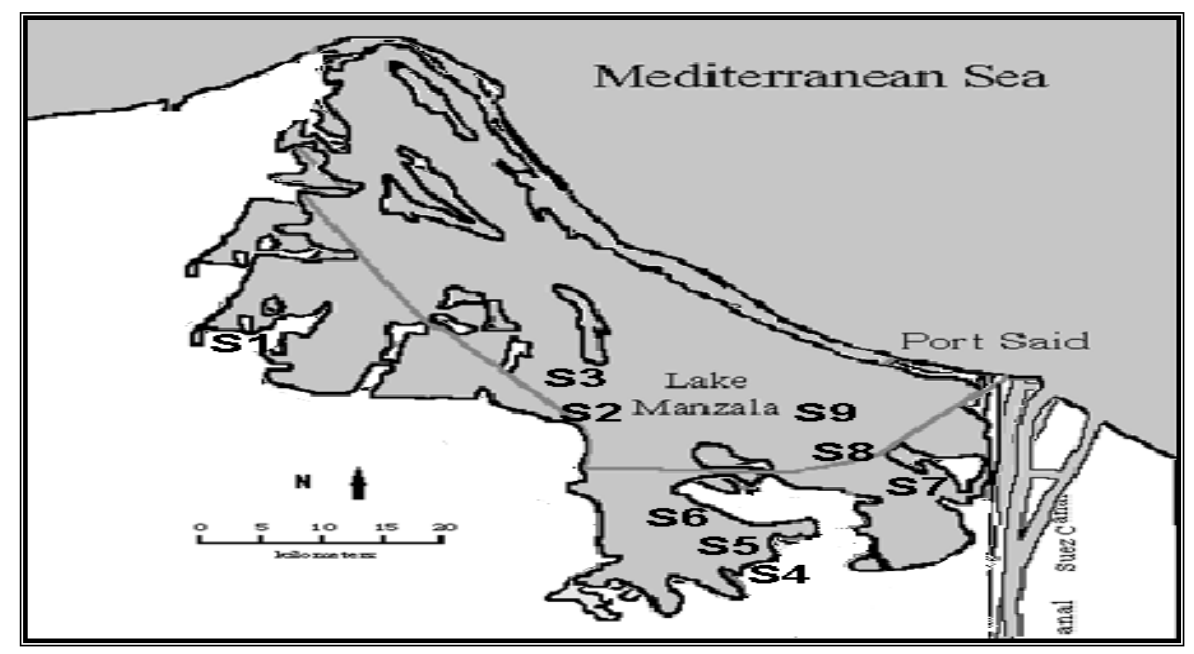

Fig. 1: Map of Lake Manzala showing location of sampling sites.

Table 1: Sampling sites in Lake Manzala with latitudes and longitudes.

\begin{tabular}{|c|c|c|c|}
\hline Station & Code & Latitude & Longitude \\
\hline El-Serw D. & S1 & $31^{\circ} 15^{\prime} 36 \mathrm{~N}$ & $31^{\circ} 50^{\prime} 54 \mathrm{E}$ \\
\hline El-Matariya & S2 & $31^{\circ} 11^{\prime} 7 \mathrm{~N}$ & $32^{\circ} 2^{\prime} 21 \mathrm{E}$ \\
\hline Legan & $\mathrm{S} 3$ & $31^{\circ} 14^{\prime} 11 \mathrm{~N}$ & $32^{\circ} 4^{\prime} 22 \mathrm{E}$ \\
\hline Old Bahar El-Bakar Drain & $\mathrm{S} 4$ & $31^{\circ} 4^{\prime} 20 \mathrm{~N}$ & $32^{\circ} 9^{\prime} 15 \mathrm{E}$ \\
\hline Old Bahar El-Bakar D.P. & $\mathrm{S} 5$ & $31^{\circ} 6^{\prime} 20 \mathrm{~N}$ & $32^{\circ} 7^{\prime} 0 \mathrm{E}$ \\
\hline El-Genka & $\mathrm{S} 6$ & $31^{\circ} 9^{\prime} 33 \mathrm{~N}$ & $32^{\circ} 5^{\prime} 59 \mathrm{E}$ \\
\hline New Bahar El-Bakar Drain & $\mathrm{S} 7$ & $31^{\circ} 10^{\prime} 46 \mathrm{~N}$ & $32^{\circ} 12^{\prime} 5 \mathrm{E}$ \\
\hline New Bahar El-Bakar D.P. & $\mathrm{S} 8$ & $31^{\circ} 12^{\prime} 16 \mathrm{~N}$ & $32^{\circ} 12^{\prime} 10 \mathrm{E}$ \\
\hline El-Boom & $\mathrm{S} 9$ & $31^{\circ} 16^{\prime} 22 \mathrm{~N}$ & $32^{\circ} 7^{\prime} 0 \mathrm{E}$ \\
\hline
\end{tabular}

D. = Drain, D.P. $=$ Discharge point.

\section{Collection and analysis}

Water and benthic invertebrate were collected from each station during spring (May, 2014) and summer (August, 2014). Chemical parameters e.g. Dissolved Oxygen (DO), Biological Oxygen Demand (BOD), Total Dissolved Solids (TDS), Ammonia $\left(\mathrm{NH}_{3}\right)$, Nitrate $\left(\mathrm{NO}_{3}\right)$, Orthophosphorus $\left(\mathrm{PO}_{4}\right)$, Total Suspended Solids (TSS) was measured in Chemistry Lab at National Institute of Oceanography-Qanater according to APHA (2005). 
The bottom fauna was collected by the Ekman Grab bottom sampler, covering an area of about $0.03 \mathrm{~m}^{2}$. After collection the bottom fauna was washed thoroughly in a small hand net of bolting silk ( $0.5 \mathrm{~mm}$ mesh size) and picked in and preserved immediately in $10 \%$ neutral formalin solution in polyethylene jars. In the laboratory, samples were washed again and each species was counted separately. The bottom fauna was identified and sorted into groups and species according to Edmondson (1966), Brown (1980\& 2001) and Bishai et al. (2000).

\section{Data analysis}

The following procedures were adopted for the Applying of the Indices:

The application of the Nile Chemical Pollution Index (NCPI):

Chemical data were collected for chemical variables including pollution indicators from a wide range of sites, including unpolluted reference sites and sites with varying levels of pollution. Pollution significance was assigned to the values of a selection of chemical parameters to produce a Nile Chemical Pollution Index (NCPI) and the NCPI score was calculated for each site.

Score of NCPI determined the pollution level of lake water by given a distinct number (NCPI score) for each selected chemical parameters for each station. There are two score types, primary significance was given to $\mathrm{BOD}, \mathrm{DO}$ and $\mathrm{NH}_{3}$ each has a maximum score in the index of (10), where 10 was equated with gross pollution and 1 with clean water. $\mathrm{NO}_{3}, \mathrm{PO}_{4}$, TSS and TDS were given secondary status in the index with a maximum of (5) indicating highly significant inputs and one equal to background levels in clean water. Table $2 \mathrm{a}$ and $\mathrm{b}$ shows the value boundaries for each score for the seven chemical variables. The scoring categories have been selected on the basis of known levels in clean and grossly polluted sites from the literature (Stiff, 1980, Armitage et al., 1983, Chapman, 1992, Fishar and Williams 2008).

Table 2: Pollution categories for the Nile Chemical Pollution Index

\begin{tabular}{|c|c|c|c|c|c|}
\hline \multicolumn{6}{|c|}{ (a) Biochemical Oxygen Demand (BOD), Dissolved Oxygen (DO) and Ammonia $\left(\mathrm{NH}_{3}\right)$} \\
\hline Description & Chem. Index & BOD mg/l & DO mg/l & \multicolumn{2}{|c|}{$\mathrm{NH}_{3} \mathrm{mg} / \mathrm{l}$} \\
\hline Excellent & 1 & $0<1$ & +7 & \multicolumn{2}{|c|}{$0<0.25$} \\
\hline Very Good & 2 & $1<2$ & $6<7$ & \multicolumn{2}{|c|}{$0.25<0.5$} \\
\hline Good & 3 & $2<4$ & $5<6$ & \multicolumn{2}{|c|}{$0.5<1$} \\
\hline Fair & 5 & $4<6$ & $3<5$ & \multicolumn{2}{|c|}{$1<2.5$} \\
\hline Poor & 7 & $6<10$ & $1<3$ & \multicolumn{2}{|c|}{$2.5<5$} \\
\hline Very Poor & 9 & $10<15$ & $0<1$ & \multicolumn{2}{|c|}{$5<10$} \\
\hline $\mathrm{Bad}$ & 10 & $15+$ & 0 & \multicolumn{2}{|c|}{$10+$} \\
\hline \multicolumn{6}{|c|}{$\begin{array}{c}\text { Nitrate }\left(\mathrm{NO}_{3}\right) \text {, Total Orthophosphate }\left(\mathrm{O}-\mathrm{PO}_{4}\right) \text {, Total Dissolved Solids ( TDS), Total } \\
\text { Suspended Solids (TSS) }\end{array}$} \\
\hline Description & Chem. Index & $\mathrm{NO}_{3} \mathrm{mg} / \mathrm{l}$ & $\mathrm{PO}_{4} \mathrm{mg} / \mathrm{l}$ & TDS mg/l & TSS \\
\hline Excellent & 1 & $0<0.1$ & $0<0.1$ & $0<200$ & $0<30$ \\
\hline Good & 2 & $0.1<0.5$ & $0.1<1.5$ & $200<300$ & $30<50$ \\
\hline Fair & 3 & $0.5<1.0$ & $0.5<1.0$ & $300<500$ & $50<100$ \\
\hline Poor & 4 & $1.0<1.5$ & $1.0<2.0$ & $500<800$ & $100<300$ \\
\hline $\mathrm{Bad}$ & 5 & $1.5+$ & $2.0+$ & $800+$ & $300+$ \\
\hline
\end{tabular}

The NCPI scoring system means that a grossly polluted station could theoretically have a score of 50 and a pristine (very clean) stations a score of 7 . Sites scoring over $36-50$ will be designated as grossly polluted, 26-35 heavily polluted, 21-25 moderately polluted, 16-20 slightly polluted, less than 15 clean.

Biological data were obtained from the same sites using reliable sampling methodology that provided a good representation of the taxa present. A preliminary analysis of these data was carried out using an unaltered UK based BMWP scoring system and calculating BMWP score (BMWP) and the BMWP Average Score Per 
Taxon (BMWP-ASPT) for each of the Nile sites. The scoring system was then refined by assigning a Nile Pollution Tolerance Scores (NPTS) to each taxonomic group found in the Nile, using the BMWP scores in most instances, but also giving scores for taxa either, for which the BMWP score was not available, or seemed inappropriate. The total NPTS scores at each site were recorded to provide a Nile Biotic Pollution Index (NBPI) and the Nile Average Score Per Taxon Index (NBPIASPT).

The BMWP scoring system was applied to identify and give a distinct value (BMWP score) for certain taxa, family level (indicatory families), which observed in each station, this score reflectes the ability of family to pollution tolerantly and therefore indicated to pollution level at each station of the lake.

All possible families having saprobic indicator value are classified on a score-scale of 1 to 10 according to their preference for saprobic water quality. The saprobic scores of all the families are registered to produce BMWP score, where families of score (1) were tolerant to pollution, while families of score 10 were very sensitive to pollution.

The application of the BMWP and BMWP-ASPT

The BMWP and average of BMWP (BMWP-ASPT) were calculated. For each station, the number of families having BMWP score was calculated, and then scores of each family were summable according to BMWP scoring system, the BMWPASPT referred to score of each station given by division the summation of families score to the number of BMWP scoring families according to the following equation;

$B M W P-A S P T=A / B$

Where; $\mathrm{A}=$ Summation of BMWP families score

$\mathrm{B}=$ No. of BMWP scoring families

According to above, each lake station has been a distinct BMWP-ASPT

NBPI; The BMWP scoring system has been used as the basis of the Nile Pollution Tolerance score (NPTS) which refereed to the number of families having a score in the NBPI index, this score was primarily based on the BMWP for the family. Pollution sensitive families scored a maximum of (10), whilst pollution tolerant species scored a minimum of (1). Where no BMWP score was available for a taxonomic group, the saprobien level assigned to the taxon was used to give a NPTS estimated score.

\section{The application of the NBPI and NBPI -ASPT to the data of Manzala}

The NBPI and average of NBPI (NBPI-ASPT) were calculated. For each station, the number of families having NBPI score (NPTS) was calculated, and then scores of each family were summable according to NBPI, the NBPI-ASPT referred to score of each station given by division the summation of families score on the number of NBPI scoring families according to the following equation;

$N B P I-A S P T=A / B$

Where; $\mathrm{A}=$ Summation of NBPI families score

$\mathrm{B}=$ No. of NBPI scoring families

According to above, each lake station has been a distinct NBPI -ASPT

Table 3: Water quality classes according to BMWP and NBPI Indices.

\begin{tabular}{|c|c|}
\hline Water quality Class & Index \\
\hline I- high & More than 8 \\
\hline II- good & $6-8$ \\
\hline III- moderate & $5-5.9$ \\
\hline IV- poor & $3.5-4.9$ \\
\hline V- bad & Less than 3.5 \\
\hline
\end{tabular}


The BMWP, the BMWP-ASPT, the NBPI and NBPI-ASPT were compared with the NCPI at the various sites to see how far these indices reflected chemical water quality. Also, regression analysis for comparing between the above indices and NCPI was carried out by Microsoft Excel and SPSS, 2007 (version16) software.

\section{RESULTS}

\section{Chemical parameters}

Dissolved Oxygen (DO) recorded the highest values at Legan station during spring and summer being 8.20 and $10.64 \mathrm{mg} / 1$ respectively, while the lowest recorded at New Bahr ElBakar D.P. during summer $(1 \mathrm{mg} / \mathrm{l})$, and Old Bahr El-Bakar D.P. $(1.68 \mathrm{mg} / \mathrm{l})$ during spring. Biological Oxygen Demand (BOD) recorded the highest value $(31.2 \mathrm{mg} / \mathrm{l})$ at Old Bahr ElBakar during spring, while the lowest 1.28 and $1 \mathrm{mg} / \mathrm{l}$ were recorded at El-Boom station during spring and summer, respectively. El-Boom station recorded the highest values of Total Dissolved Solids (TDS) during summer and spring as 5981 and $3956 \mathrm{mg} / 1$ respectively, where El-Serw D. recorded a lowest TDS values as 895 and $866 \mathrm{mg} / \mathrm{l}$ during summer and spring, respectively (Table, 4).

Table 4: Chemical Parameters at the selected stations in Lake Manzala during study.

\begin{tabular}{|c|c|c|c|c|c|c|c|c|}
\hline Stations & Seasons & $\begin{array}{c}\text { TDS } \\
(\mathrm{mg} / \mathrm{l})\end{array}$ & $\begin{array}{c}\text { DO } \\
(\mathrm{mg} / \mathrm{l})\end{array}$ & $\begin{array}{l}\text { BOD } \\
(\mathrm{mg} / \mathrm{l})\end{array}$ & $\begin{array}{c}\mathrm{NO}_{3} \\
(\mathrm{mg} / \mathrm{l})\end{array}$ & $\begin{array}{l}\mathrm{NH}_{3} \\
(\mathrm{mg} / \mathrm{l})\end{array}$ & $\begin{array}{c}\mathrm{PO}_{4} \\
(\mathrm{mg} / \mathrm{l})\end{array}$ & $\begin{array}{l}\text { TSS } \\
\text { (mg/l) }\end{array}$ \\
\hline \multirow{2}{*}{ El-Serw D. } & Spring & 895 & 2.80 & 7.80 & 0.09 & 2.54 & 0.17 & 200 \\
\hline & Summer & 866 & 1.68 & 4.32 & 0.17 & 4.23 & 0.19 & 280 \\
\hline \multirow{2}{*}{ El-Matarya } & Spring & 1796 & 2.60 & 14.40 & 0.05 & 1.03 & 0.21 & 60 \\
\hline & Summer & 1780 & 7.20 & 5.92 & 0.27 & 1.77 & 0.24 & 380 \\
\hline \multirow[t]{2}{*}{ Legan } & Spring & 4540 & 10.64 & 1.40 & 0.03 & 0.08 & 0.18 & 40 \\
\hline & Summer & 2412 & 8.20 & 7.80 & 0.10 & 0.21 & 0.14 & 360 \\
\hline \multirow{2}{*}{$\begin{array}{l}\text { Old Bahr } \\
\text { Bakar D. }\end{array}$} & Spring & 4356 & 2.04 & 31.20 & 0.03 & 0.69 & 0.23 & 260 \\
\hline & Summer & 2861 & 1.36 & 16.80 & 0.20 & 8.76 & 0.35 & 700 \\
\hline \multirow{2}{*}{$\begin{array}{l}\text { Old Bahr } \\
\text { Bakar D.P }\end{array}$} & Spring & 3734 & 1.68 & 14.40 & 0.04 & 3.54 & 0.33 & 230 \\
\hline & Summer & 2846 & 3.20 & 15.50 & 0.15 & 9.31 & 0.35 & 600 \\
\hline \multirow{2}{*}{ El-Genka } & Spring & 3619 & 2.80 & 1.40 & 0.03 & 0.14 & 0.22 & 200 \\
\hline & Summer & 3250 & 4.64 & 5.50 & 0.42 & 2.59 & 0.23 & 380 \\
\hline \multirow{2}{*}{$\begin{array}{l}\text { New Bahr } \\
\text { Bakar D. }\end{array}$} & Spring & 3278 & 2.80 & 24.00 & 0.06 & 5.30 & 0.47 & 360 \\
\hline & Summer & 2986 & 1.08 & 14.40 & 0.38 & 7.68 & 0.49 & 420 \\
\hline \multirow{2}{*}{$\begin{array}{l}\text { New Bahr } \\
\text { Bakar D.P }\end{array}$} & Spring & 3279 & 4.00 & 30.20 & 0.04 & 0.10 & 0.40 & 320 \\
\hline & Summer & 2925 & 1.00 & 14.00 & 0.18 & 8.08 & 0.45 & 390 \\
\hline \multirow{2}{*}{ El-Boom } & Spring & 5981 & 1.72 & 1.00 & 0.05 & 0.16 & 0.14 & 200 \\
\hline & Summer & 3956 & 2.48 & 1.28 & 0.10 & 1.53 & 0.13 & 300 \\
\hline
\end{tabular}

D. = Drain, D.P. $=$ Discharge point.

The highest values of ammonia were recorded during summer $(9.3 \mathrm{mg} / \mathrm{l})$ at Old Bahr El-Bakar D. P. and New Bahr El-Bakar D. (5.3 mg/l) during spring, while the lowest values recorded at Legan station $(0.21$ and $0.08 \mathrm{mg} / \mathrm{l})$ during summer and spring respectively. At ElGenka and New Bahr El-Bakar D. stations, the highest nitrite value was observed during summer being 0.42 and $0.38 \mathrm{mg} / 1$ respectively while the lowest value of nitrate $(0.03 \mathrm{mg} / \mathrm{l})$ was recorded during summer at Old Bahr El-Bakar D. and Legan station during spring. Orthophosphorus recorded the highest values at New Bahr El-Bakar D. being $0.49 \mathrm{mg} / 1$ \& $0.47 \mathrm{mg} / \mathrm{l}$ in spring and summer respectively, while the lowest values were observed at Legan $(0.18 \mathrm{mg} / \mathrm{l})$ during spring and El-Boom station during summer $(0.13 \mathrm{mg} / \mathrm{l})$.

\section{Structure of Macrobenthic Invertebrates (MBI)}

Nineteen MBI species were recorded during the study belonging to three main groups; Mollusca, Annelida and Arthropoda. Mollusca recorded the highest species (15 species), while Annelida and Arthropoda recorded the lowest being 2 species for both of them. During the study, the highest number of species (19 species) was recorded during summer, while the 
lowest one was observed during spring (17 species). At all the studied stations, Legan recorded the highest number of species (16 species) during summer and (13 species) during spring, also El-Boom station recorded (14 species) during summer. The lowest number of species was observed at Old Bahr El-Bakar Drain and its discharged point being 4 and 3 species respectively.

Eighteen families were recorded during the study; out of them 8 families are bioindicatory families (Viviparidae, Planorbidae, Lymnaeidae, Thiaridae, Physidae, Neritidae Tubificidae and Chironomidae) which used in the applied biotic indices.

Table 5: Occurrence of macrobenthic invertebrates during spring.

\begin{tabular}{|c|c|c|c|c|c|c|c|c|c|c|}
\hline Group and Family & Species & S1 & S2 & S3 & S4 & S5 & S6 & S7 & S8 & S9 \\
\hline \multicolumn{11}{|l|}{ Mollusca } \\
\hline Viviparidae & Bellamya unicolor & + & + & + & - & + & + & + & - & + \\
\hline \multirow{2}{*}{ Planorbidae } & Biomphlaria alexandrina & - & + & - & + & - & + & - & + & + \\
\hline & Bulinus truncatus & - & - & + & - & - & + & + & - & - \\
\hline Paludomidae & Cleopatra bulimoides & - & + & + & - & - & + & - & - & + \\
\hline Ampullariidae & Lanistes carinatus & - & - & - & - & - & - & - & - & - \\
\hline Lymnaeidae & Lymnaea natalensis & - & - & + & - & + & + & - & - & + \\
\hline Thiaridae & Melanoides tuberculata & + & + & + & + & + & + & + & + & + \\
\hline Physidae & Physa acuta & - & - & - & - & - & - & - & - & - \\
\hline Potamididae & Pirenella conica & - & + & + & - & - & - & - & - & + \\
\hline Succineidae & Succinea cleopatra & - & - & - & - & - & - & - & - & - \\
\hline Neritidae & Theodoxus niloticus & - & - & + & - & - & - & - & - & - \\
\hline Valvatidae & Valvata nilotica & - & - & - & - & - & - & - & - & - \\
\hline Cardiidae & Cerastoderma glaucum & - & + & + & + & - & + & + & + & - \\
\hline Corbiculidae & Corbicula fluminalis & - & + & + & - & - & - & - & - & - \\
\hline Tellinidae & Macoma cumana & - & - & + & + & - & + & - & - & + \\
\hline \multicolumn{11}{|l|}{ Annelida } \\
\hline Naididae & Chaeto gasterlamnaei & + & + & + & - & - & - & - & + & - \\
\hline Tubificidae & Limnodrilus sp. & + & + & + & - & - & - & - & + & - \\
\hline \multicolumn{11}{|l|}{ Arthropoda } \\
\hline Balanidae & Balanus amphitrite & - & - & - & - & - & - & - & - & - \\
\hline Chironomidae & Chironomus larvae & - & - & + & - & - & - & - & + & - \\
\hline
\end{tabular}

Table 6: Occurrence of macrobenthic invertebrates during summer.

\begin{tabular}{|c|c|c|c|c|c|c|c|c|c|c|}
\hline Family & Species & S1 & S2 & S3 & $\mathbf{S 4}$ & S5 & S6 & S7 & S8 & S9 \\
\hline \multicolumn{11}{|l|}{ Mollusca } \\
\hline Viviparidae & Bellamya unicolor & + & + & + & + & - & + & - & + & + \\
\hline \multirow{2}{*}{ Planorbidae } & Biomphlaria alexandrina & - & + & + & + & + & + & + & + & + \\
\hline & Bulinus truncatus & - & - & + & - & - & - & - & - & + \\
\hline Paludomidae & Cleopatra bulimoides & - & - & + & - & - & - & - & - & - \\
\hline Ampullariidae & Lanistes carinatus & - & + & - & - & - & - & - & - & + \\
\hline Lymnaeidae & Lymnaea natalensis & - & - & + & - & - & - & - & - & + \\
\hline Thiaridae & Melanoides tuberculata & + & + & + & + & + & + & - & + & + \\
\hline Physidae & Physa acuta & - & & + & + & & + & - & + & + \\
\hline Potamididae & Pirenella conica & - & + & + & + & + & + & - & + & + \\
\hline Succineidae & Succinea cleopatra & - & - & + & - & - & - & - & - & - \\
\hline Neritidae & Theodoxus niloticus & - & + & - & - & - & - & - & - & + \\
\hline Valvatidae & Valvata nilotica & - & + & + & + & - & + & - & - & - \\
\hline Cardiidae & Cerastoderm aglaucum & - & + & + & + & - & + & - & + & + \\
\hline Corbiculidae & Corbicula fluminalis & - & + & + & + & - & + & - & + & + \\
\hline Tellinidae & Macoma cumana & - & + & + & + & + & + & - & - & - \\
\hline \multicolumn{11}{|l|}{ Annelida } \\
\hline Naididae & Chaetogaster sp. & - & - & - & - & - & - & - & - & - \\
\hline Tubificidae & Limnodrilus sp. & - & + & + & - & - & - & + & - & + \\
\hline \multicolumn{11}{|l|}{ Arthropoda } \\
\hline Balanidae & Balanus amphitrite & - & + & + & - & + & + & - & + & + \\
\hline Chironomidae & Chironomus larvae & + & + & + & + & - & - & + & + & + \\
\hline
\end{tabular}




\section{Pollution Indices:}

At all the selected stations the pollution levels of the Lake Manzala based on applying three indices; Nile Chemical Pollution Index (NCPI), Biological Monitoring Working Party (BMWP) and Nile Biotic Pollution Index (NBPI) were conducted (Table, 7). NCPI reflects the chemical quality of the lake water according to the data from some chemical pollution parameters e.g. Dissolved Oxygen (DO mg/l), 5 days Biological Oxygen Demand (BOD mg/l), Total Dissolved Solids (TDS mg/l), Total Suspended Solids (TSS mg/l), Ammonia $\left(\mathrm{NH}_{3} \mathrm{mg} / \mathrm{l}\right)$, Nitrate $\left(\mathrm{NO}_{3} \mathrm{mg} / \mathrm{l}\right)$ and Total Phosphate $\left(\mathrm{PO}_{4} \mathrm{mg} / \mathrm{l}\right)$.

Table 7: The applied NCBI, BMWP-ASPT and NBPI-ASPT indices in Lake Manzala during Spring and summer, 2014.

\begin{tabular}{|l|c|c|c|c|c|c|}
\hline \multicolumn{1}{|c|}{ Season } & \multicolumn{3}{c|}{ Spring } & \multicolumn{3}{c|}{ Summer } \\
\hline Station & NCBI & BMWP-ASPT & NBPI-ASPT & NCBI & BMWP-ASPT & NBPI-ASPT \\
\hline El-Serw D. & 32 & 3.5 & 1.0 & 36 & 4.7 & 3.7 \\
\hline El-Matarya & 26 & 3.6 & 3.0 & 32 & 4.0 & 3.4 \\
\hline Legan & 26 & 3.5 & 3.0 & 14 & 3.6 & 3.0 \\
\hline Old Bahr Bakar D. & 40 & 3.0 & 3.0 & 32 & 4.2 & 2.3 \\
\hline Old Bahr Bakar D.P & 38 & 3.0 & 3.0 & 35 & 4.5 & 3.0 \\
\hline El-Genka & 31 & 3.0 & 3.0 & 22 & 3.0 & 3.5 \\
\hline New Bahr Bakar D. & 40 & 3.0 & 3.0 & 39 & 2.0 & 2.0 \\
\hline New Bahr Bakar D.P & 40 & 2.0 & 2.0 & 29 & 3.6 & 3.0 \\
\hline El-Boom & 27 & 2.3 & 2.3 & 22 & 4.2 & 3.8 \\
\hline Average & 33 & 3.0 & 2.6 & 29 & 3.8 & 3.1 \\
\hline
\end{tabular}

D.= Drain, D.P.= Discharge point.

NCBI was applied on the lake stations during spring to find that the highest score (40) were observed at Old Bahr Bakar D., New Bahr Bakar D. and New Bahr Bakar D.P. This score (40) indicates grossly polluted area, followed by station Old Bahr Bakar D.P given score (38) which also indicates grossly polluted station, while stations El-Serw D. (score 32), El-Genka (31) and El-Boom (score 27) indicating heavily polluted stations. Stations El-Matarya and Legan had the lowest score (26) indicating to heavily polluted area, that means the pollution level of lake water in spring ranged from heavily to grossly polluted range. Similarly, NCBI was applied on the lake stations in summer to find that the highest stations score were New Bahr Bakar (score 39) and El-Serw D. (score 36) indicating to grossly polluted stations, followed by stations Old Bahr Bakar D.P (score 35), Old Bahr Bakar D. (score 32), El-Matarya (score 32) and New Bahr Bakar D.P (score 29) indicating to heavily polluted stations. Stations El-Genka and El-Boom were given score of (22) indicating to moderately polluted stations. The only station Legan (score 14) indicating clean area, that means the pollution level of lake water in summer ranged from clean to grossly polluted range.

\section{The application of the BMWP and BMWP-ASPT}

During spring, the results showed that the highest stations values were observed at El-Matarya (score 3.6), El-Serw D. (score 3.5) and Legan (score 3.5), while the lowest was observed at New Bahr Bakar D.P station (score 2.00). During summer, the highest stations score were; El-Serw D. (score 4.7) and Old Bahr Bakar D.P (score 4.5), while the lowest was at New Bahr Bakar D. (score 2.00). 


\section{The application of the NBPI and NBPI -ASPT to the data of Manzala}

In spring, the results revealed that the highest stations NBPI values (sore 3.00) were; El-Matarya, Legan, Old Bahr Bakar D., Old Bahr Bakar D.P, El-Genkaand New Bahr Bakar D., while the lowest was recorded at El-Serw D. (score 1.00). During summer, the highest station score was New Bahr Bakar D.P (score 3.8), while the lowest was at New Bahr Bakar D. (score 2.00).

\section{Regression Analysis}

Regression between the chemical (NCBI), BMWP-ASPT and NBPI Indices showed unsignificant values ( $\mathrm{p}$ value more than 0.05 ) during spring and summer (Table 8 and Fig. 2). The $\mathrm{p}$ value between NCBI and BMWP-ASPT recorded the highest value $\left(\mathrm{p} \leq 1, \mathrm{r}^{2}=0.0\right)$ during summer, while between NCBI and NBPI-ASPT it recorded the highest value during $\operatorname{spring}\left(\mathrm{p} \leq 0.97, \mathrm{r}^{2}=0.0\right)$.

Table 8: Regression between the chemical index (NCBI) and the other biotc indices (BMWP and NBPI Index).

\begin{tabular}{|c|c|c|c|c|}
\hline \multirow{2}{*}{ Regression output } & \multicolumn{2}{|c|}{ spring } & \multicolumn{2}{c|}{ summer } \\
\cline { 2 - 5 } & P value & $\mathrm{r}^{2}$ & $\mathrm{p}$ value & $\mathrm{r}^{2}$ \\
\hline NCBI$^{*}$ BMWP-ASPT & 0.28 & 0.17 & 1.00 & 0.00 \\
\hline NCBI*NBPI-ASPT & 0.97 & 0.00 & 0.31 & 0.02 \\
\hline
\end{tabular}

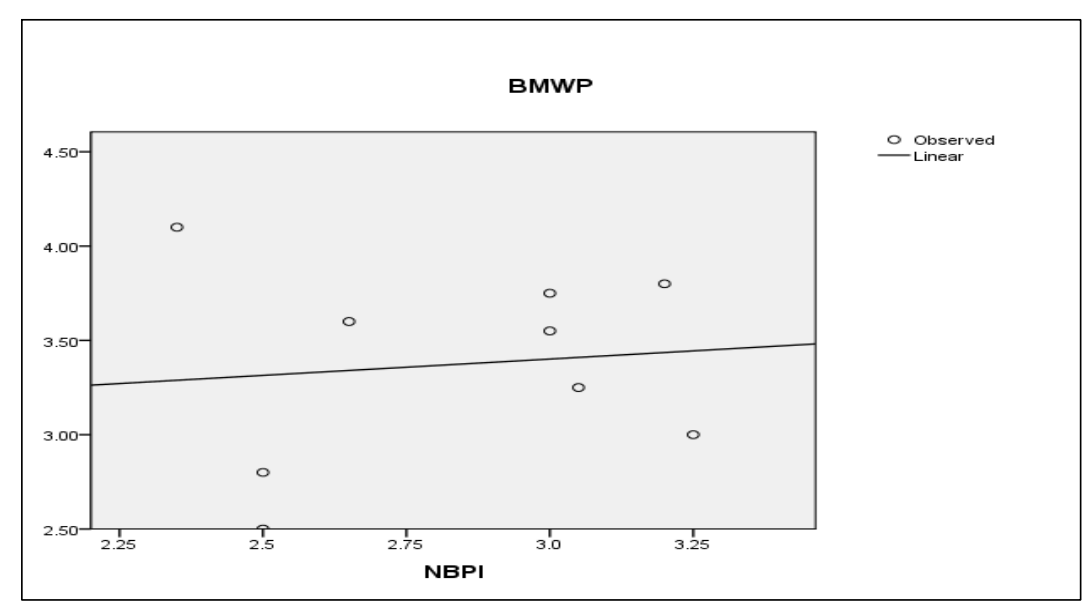

Fig. 2: Linear regression for BMWP and NBPI indices depending on macrobenthic invertebrates in Lake Manzala.

\section{DISCUSSION}

The highest number of macrobenthic invertebrates and the best water quality were observed at the stations away from source of pollution e.g. Legan Station and Boom while the lowest water quality and the lowest number of species was observed at Bahr El-Bakar and its discharge point. This agreed with Mola (2004) and Mola \& Abdel Rashid (2012). The present study revealed that, the average values of NCBI was ranged between 33 during spring and 29 during summer, this indicating heavily polluted range (26-35). The Egyptian National Environmental Action Plan of 1992 identified Lake Manzala as among the most heavily polluted water bodies in the country. It is considered one of the most important lakes in Egypt that is exposed to high levels of pollutants from industrial, domestic and agricultural resources (Badawy and Wahaab, 1997; Abdel-Baky et al., 1998b; Ibrahim et al., 1999). Also, by applying the biological index BMWP-ASPT, the highest values 4.7 was observed at El-Serw drain during summer, while the lowest (2) was observed at New Bahr El-Bakar D. and its discharged point during spring and summer respectively. For NBPI-ASPT, the 
highest score was observed at El-Boom station (3.8). This means that these biological indices are less than five (poor and bad pollution level) and this reflects the pollution state of the lake.

The effect of pollution is most noticed along the whole lake. At the southern part of Lake Manzala at Bahr El Baqar Drain, the water became a repulsive brown and the smell changes from the freshness to the stench of sewage (Abdel-Gawad and El- Sayed, 1998). The pollution loads flowing from the major water systems into Lake Manzala are mainly by Bahr El Baqar Drain. The total discharged water to Lake Manzala was ca $4 \times 10^{9} \mathrm{~m}^{3} /$ year (Abdel-Mageed, 2007). Macrobenthic invertebrates exposure to chemical contaminants often accumulated in the sediment; exposure to low dissolved oxygen levels (hypoxia/anoxia) that often occur near the bottom surface due to organic matter degradation; limited mobility that restricts their ability to avoid adverse conditions; taxonomic and functional diversity that make them suitable for the detection of different types and levels of stress (Tagliapietra and Sigovini, 2010). The benthic oligochaets recorded during study were dominant with Limnodrilus sp. indicating it's tolerant to organic and metal pollution. These observations agreed with Mola \& Abdel Gawad (2014) and Alagoa \& Aleleye-Wokoma (2015).

There are 19 MBI species under 18 families were recorded; out of these 8 families are bioindicatory families (Viviparidae, Planorbidae, Lymnaeidae, Thiaridae, Physidae, Neritidae, Tubificidae and Chironomidae) which used in the applied biotic indices. During spring, the average value of NCBI recorded high score (33), whereas BMWP-ASPT and NBPI-ASPT were decreased being 2.99 and 2.59 respectively. Vice versa, the average value of NCBI during summer recorded low scores (29), whereas BMWP-ASPT and NBPI-ASPT were increased. The present study does not coincided with Fishar and Williams (2008) which mentioned that, both the NBPI and the NBPI-ASPT have been shown to provide an excellent biological assessment of organic pollution in the Nile and would provide a very useful adjunct to chemical monitoring of water quality.

Various biotic indices were developed, for use in both developed and developing countries, but to date no such index is available for use in Egypt and specifically for Manzala Lake. Various technical developments have been achieved in the use of benthic macro invertebrates as advantageous biomonitors in stream ecosystems (Sultana and Kala, 2012).

Regression analysis between the chemical index (NCBI) and BMWP-ASPT Index and NBPI Index showed a non significant values ( $p$ value more than 0.05 ) during spring and summer. So, the study concluded that, BMWP-ASPT and NBPI Indices not give a good indication to assess water quality of Lake Manzala and not matching with chemical index (NCBI) and more developments for these indices are needed to develop them according to the nature of the lake and their dominant macrobethic indicator species.

\section{ACKNOWLEDGMENTS}

The authors would like to thank Dr. Mohamed El-Sherif Goher and Dr. Afify Dardir for their help and providing data of chemical parameters as members of Lake Manzala project funded by National Institute of Oceanography and Fisheries. 


\section{REFERENCES}

Abdel-Gawad, S. T. and El-Sayed, A. (1998). An approach to identify the pollution field in Lake Manzala. In: Conference on coping with water scarcity, Hurghada, Egypt, 28 August, 1998. 4(3):1-10.

Alagoa, K. J. and Aleleye-Wokoma, I. P. (2015). Variations of Benthic MacroInvertebrates in Taylor Creek, Biseni, Bayelsa State, Nigeria. Int. J. Curr. Res. Biosci. Plant Biol. 2(2): 49-54.

Arora, H. C. (1966). Rotifera as indicator of trophic nature of environments. Hydrobiol., 27: 146-159.

APHA (American Public Health Association), (2005). Standard methods for examination of water and wastewater. $21^{\text {st }}$ Edn. Standard Methods is a joint publication of the American Public Health Association (APHA), the American Water Works Association (AWWA), and the Water Environment Federation (WEF). Washington DC, USA.

Barbour, M. T.; Gerritsen, J.; Snyder, B. K. and Stribling, J. B. (1999). Rapid bioassessment protocols for use in streams and wadeable rivers. Periphyton, benthic macroinvertebrates and fish. Second Edition. Assessment and Water Protection Division, U.S. Environmental Protection Agency. Report EPA, Washington, D.C.

Beatty, J. M.; McDonald, L. E.; Westcott, F. M. and Perrin, C. J. (2006). Guidelines for sampling benthic invertebrates in british columbia streams.

British Columbia, Ministry of environment, Updated January 2006

Bishai, H. M.; Abdel Malek, S. A. and Khalil, M. T., (2000). Lake Nasser. Egyptian Environmental Affairs Agency (EEAA production). National Biodiversity Unit. No. 11.

Bishai, M. H. and Yossef, S. F. (1977). Some aspects on the hydrography, physiochemical characteristics and fisheries of lake Manzala. Bull. Inst. Ocean and fish, A.R.E., 7: 31-51

Brown, D. S. (1980). Freshwater snails of Africa and their medical importance. Lond., Taylor \&Francis Ltd.

Brown, K. M. (2001). Mollusca: Gastropoda. In: Thorp, J. H., Covich, A. P.(Eds)., Ecology and Classification of North American Freshwater Invertebrates. Academic press, pp. 297-329.

Chapin, F. S. (1998). Ecosystem consequences of changing biodiversity. Bio-Science, 48: $45-52$.

Chapin, F. S. (2000). Consequences of Changing Biodiversity Nature, 405: 234-242. composition and productivity in Lake Manzala, Egypt. Proc. Zool. Soc. ARE, 12:101-109.

Dinar, A. (1995). Restoring and protecting the world's lakes and reservoirs. World Bank Publications. ISBN 0-8213-3321-6.

Donia, N. and Hussein, M. (2004). Eutrophication assessment of Lake Manzala using GIS techniques. $8^{\text {th }}$ International Water Technology Conference, Alexandria, Egypt, pp. 308-393.

Drower, M. S. (1995). Flinders Petrie: a life in archaeology (Second edition). ASCE Publications. p. 72. Retrieved 2009-04-10.

Edmondson, W.T., 1966. Freshwater Biology. $2^{\text {nd }}$ Edn. John Wiley and Sons. Inc. New York \& London.

Fishar, R. M. and Williams, W. P. (2008). The development of a Biotic Pollution Index for the River Nile in Egypt, Hydrobiolog., 598: 17-34. 
Gaufin, A. R. (1973). Use of aquatic invertebrates in the assessment of water quality. Biological Methods for the Assessment of Water Quality, ASTM STP 528, Ame rican Society for Testing and Materials, pp. 96-116.

Hellawell, J. M., (1986). The Biological Surveillance of Rivers; A Biological Monitoring Handbook. Water Research Centre, Stevenage, 333 pp.

karr, J. R. (1991). Biological integrity: a long-neglected aspect of water resource management. Ecol. Appl., 1: 66- 84.

Karr, J. R. (1996). Ecological integrity and ecological health are not the same. National Academy Press, Washington, DC. 175 pp.

Karr, J.R. and E.W. Chu. (1997). Biological monitoring and assessment: Using multi metric indexes effectively. Report EPA/235-R97-001, Office of Planning and E valuation, U.S. Environmental Protection Agency, Washington D.C.

Khalifa, N. and Mageed, A. (2002). Some ecological aspects on the zooplankton in Lake Manzala, Egypt. Egypt. J. Zool. 38: 293-307.

Khalil, M.T. and Salib, E.A. (1986). Effects of some water quality parameters on fish composition and productivity in Lake Manzala, Egypt. Proc. Zool. Soc. A.R. Egypt, 12: 101-109.

Lenat, D.R. and J.K. Crawford. (1994). Effects of land use on water quality and aquati c biota of three North Carolina Piedment streams. Hydrobiologia, 294:185-199.

Kolkwitz, R. and Marsson, M. (1902). Grundsätze für die biologische Beürteilung des Wassers nach seiner Flora and Fauna. Mitt.Prüfungsanst. Wasserversorg. bwasserreinig, 1: 33-72.

Mageed, A. A. (2007). Distribution and long-term historical changes of zooplankton assemblages in lake Manzala (south mediterranean sea, Egypt). Egypt. J. Aquat. Res., 33(1):183-192.

McGeoch, M. A. 1998. The selection, testing and application of terrestrial insects as bioindicators. Biological Reviews of the Cambridge Philosophical Society 73:181-201.

Miserendino, M. L. and Pizzolon, L. A. (1999). Rapid assessment of river water quality using macroinvertebrates: a family level biotic index for the Patagonic Andean zone, Acta limnological Brasileira, 11(2) 137-148.

Mola, H. R. (2011). Seasonal and spatial distribution of Brachionus (Pallas, 1966; Eurotatoria: Monogonanta: Brachionidae), a bioindicator of eutrophication in lake El-Manzalah, Egypt. Biology and Medicine, 3 (2): 60-69.

Mola, H. R. (2004). Ecological and biological studies on Lake El-Manzalah with special reference to their water quality and sediment productivity. Faculty of Science, Al-Azhar University.

Mola, H.R.A. and Abdel Gawad S.S. (2014). Spatio-temporal variations of macrobenthic fauna in Lake Nasser Khors, Egypt. (2014). Egypt. J. Aquat. Res., 40: 415-423.

Mola, H. R. and Abdel Rashid M. (2012). Effect of drains on the distribution of zooplankton at the southeastern part of Lake Manzala, Egypt. Egypt. J. Aquat. Biol. Fish., 16 (4): 57-68.

New, T.R. (1995). An Introduction to Invertebrate Conservation Biology. Oxford University Press. Oxford. 347 pp.

Norris, R.H. and C.P. Hawkins, (2000). Monitoring river health. Hydrobiologia, 435: 5-17.

Paine, R. T. (1966). Food web complexity and species diversity. American Naturalist, 100: $65-75$.

Plafkin, J.L., M.T. Barbour, K.D. Porter, S.K. Gross and R.M. Hughs (1989). Rapid 
bioassessment protocols for use in streams and rivers: Benthic macroinvertebra tes and fish. Assessment and Water protection Division, U.S. Environmental Pr otection Agency. Report EPA/440/4-89-001. Washington, D.C.

Pourriot, R. (1976). Reflexions sur les rotiferes en tant qu'indicateurs biologiques. Bulletin Français de Pisciculture, 260: 148-152.

Ramadan, A. A. (2002). Population dynamics and multivariatiate analysis of vegetation in lake Manzala, Egypt, Pakistan Journal of Biological Sciences 5(8): 842-852.

Rogers, J. R., Owen, G. and Garbrecht, J.D. (2004). Water Resources and Environmental History. ASCE Publications. p.124.

Sultana, R. and Kala, D. S., (2012). Water body quality analysis by benthic macro invertebrates, ijpbs, 2(1): 269-279.

Tagliapietra, D. and Sigovini, M. (2010). Benthic fauna: collection and identification of macrobenthic invertebrates, NEAR Curriculum in Natural Environmental Science, 2010, Terre et Environnement, 88: 253-261.

Yoon, I.B.; Bae, Y. J.; Lee, H.C. and Lee, S.J. (2001). Long-term change of aquatic insect community in the Wangsuk Creek near Seoul caused by environmental change in the drainage area. Korean J. Environ. Biol., 11 (2): 97-109.

Zahran, M. A. (2008). The Vegetation of Egypt. Springer. ISBN 1-4020-8755-1.

\section{ARABIC SUMMARY}

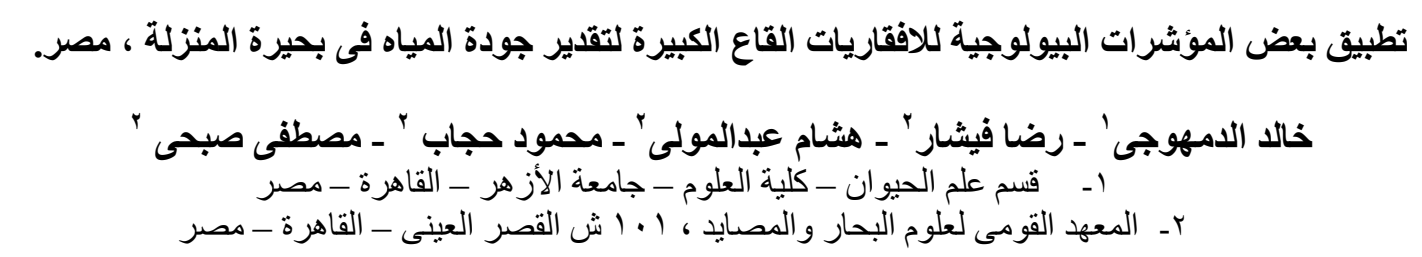

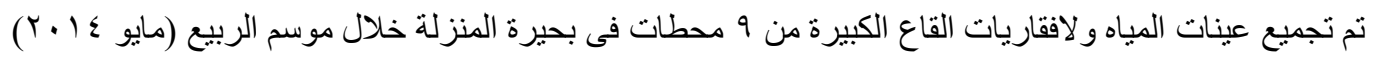

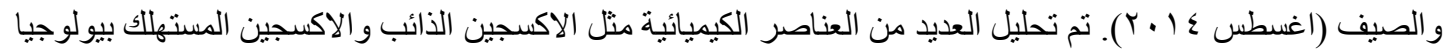
و الأملاح الذائبة الكلية والامونياو النيتريت والاورثوفوسفات والأملاح الكلية العالقة وذلك لقياس مؤشر التلوث الكيميائى للنيل (NCPI). تم فصل وتعريف لافقاريات القاع الكبيرة وذلك لحساب المؤشرات البيولوجية (BMWP) و و (NBPI)

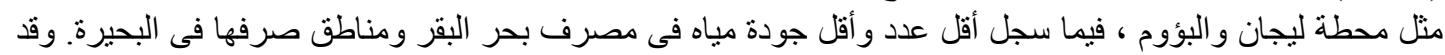

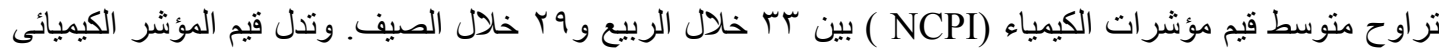

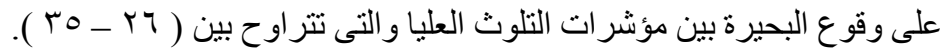

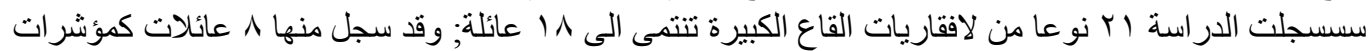

للتلوث و هى Viviparidae, Planorbidae, Lymnaeidae, Thiaridae, Physidae, Neritidae, Tubificidae and Chironomidae) للمؤشر الكيميائى بينما متوسط المؤشرات البيولوجية (BMWP) و ( NBPI) سجلت اقل قيمها، و على العكس خلال

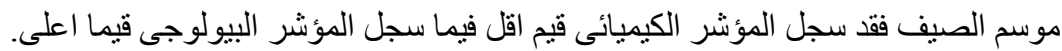

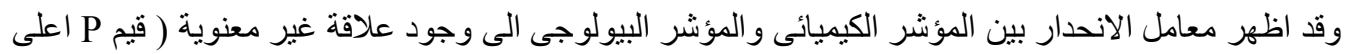

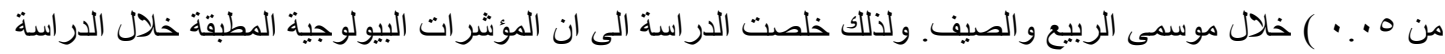

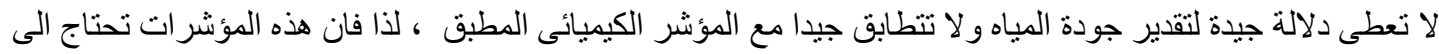
المزيد من التطوير لتتناسب مع طبيعة البحيرة وكذلك اللافقاريات القاعية الكبيرة الثائعة فيها. 